\title{
Notes on the flora of the Yucatan Peninsula VI: CAPRARIA MEXICANA MORIC. EX BENTH. (SCROPHULARIACEAE S.S.), NEW RECORD AND SOME COMMENTS ABOUT THE GENUS IN THE REGION
}

\author{
Rodrigo Duno-de Stefano', Germán Carnevali Fernández-Concha, Ivón M. \\ Ramírez-Morillo, José Luis Tapia, Silvia Hernández-Aguilar, \\ Lilia LoRena CAN-ItZa AND FIlogonio May-Pat. \\ Herbarium CICY, Centro de Investigación Científica de Yucatán, A.C. (CICY), Calle 43 No. 130, Col. Chuburná de \\ Hidalgo, 97200 Mérida, Yucatán, México. Tel 52 (999) 9813923, 9813914; Fax (999) 9813900. \\ ${ }^{1}$ Author to whom reprint requests should be addressed; e-mail: roduno@cicy.mx
}

\begin{abstract}
Capraria mexicana Moric. ex Benth. is reported for the first time from the Mexican portion of the Yucatan Peninsula Biotic Province. An overview of the genus Capraria in the region is presented. A key to the three species known for the area is provided.

Key words: Capraria, Mexico, Scrophulariaceae, Yucatan Peninsula Biotic Province.

Resumen: Capraria mexicana Moric. ex Benth. es reportada por primera vez para la porción mexicana de la Provincia Biótica Península de Yucatán. Además, se realizan comentarios generales sobre el género Capraria y se incluye una clave para identificar las tres especies que crecen en la región.

Palabras clave: Capraria, México, Scrophulariaceae, Provincia Biótica Península de Yucatán.
\end{abstract}

$\mathbf{T}$ he genus Capraria L. is a member of the Scrophulariaceae s.s. (Tank et al., 2006). There are several treatments for the genus, Williams' (2004) being the most recent. The genus comprises four species; these are herbs or small shrubs occurring in the Neotropics (now introduced in Asia) with greatest diversity in North America and Mexico, where three species are found, the fourth species being a native of Peru and Ecuador.

In Mexico, Méndez Larios and Villaseñor Ríos (2001) published a synoptic list of the family Scrophulariaceae which included the genus Capraria. They listed four species; C. biflora L., C. frutescens (Mill.) Britton, C. integrifolia M. Martens et Galeotti, and $C$. saxifragifolia Schltdl. et Cham. (herein treated as conspecific with $C$. frutescens) but not $C$. mexicana Moric. ex Benth. Study of the type specimen of Capraria integrifolia by Williams
(2004) resulted in its referral to the genus Nama L. ( $N$. jamaicense L., a taxon now included within the Boraginaceae but formerly treated as a member of Hydrophyllaceae). Thus, this species will not further be dealt with in this paper.

We basically agree with Williams' (2004) species definitions despite inconsistencies in some descriptive terminology, measurements, and character state circumscriptions. A true discrepancy on stamen relative sizes in Williams's circumscription of Capraria biflora is worth further comment and will be addressed below.

On the other hand, all of the recent floristic checklists of the Yucatan Peninsula Biotic Province including Belize and Guatemala (Sosa et al., 1985; Balick et al., 2000; Durán et al., 2000; Gutiérrez, 2000; Arellano-Rodríguez et al., 2003) included only two names for the region: Capraria 
biflora and Capraria frutescens (as C. saxifragifolia). Nevertheless, the study of all the material of Capraria housed in the herbaria CICY, MEXU, UCAM, and UADY has disclosed a third morphotype of the genus that unambiguously corresponds to Capraria mexicana. This species represents a new record for the Mexican portion of the Yucatan Peninsula Biotic Province.

Below we offer a key to the species of the genus in the area as well as for Mexico and Mesoamerica. In addition, some comments about the three species covered are included.

\section{Key to the species of the genus Capraria:}

1. Stems monopodial; pedicel 1-4 mm long; calyx indumented with hairs which can be either glandular or not, with obtuse to broadly acute, oblanceolate lobes; corolla strongly zygomorphic, bilabiate, generally white with purple or totally purple, lobes of the corolla evidently shorter than the tube, the apices rounded to emarginate to retuse; stamens included, 4, didynamous; stigma hemi-spheroid with the base concave (reniform in outline), almost two times wider than long.. Capraria frutescens 1. Stems branched; pedicel 5-25 mm long; calyx hirsute with eglandular hairs or glabrous, with lanceolate, acute to acuminate lobes; corolla ranging from slightly zygomorphic into actinomorphic, never bilabiate, completely white or cream-white, lobes of the corolla evidently longer than the tube, the apices acute; stamens slightly to long-exserted, 4 or 5 , when 4 either isomerous, didynamous, or one longer than the other three; when 5, then either isomerous, or two longer, to sometimes only one longer; stigma ovoid to ellipsoid, almost 1.3-3 times longer than wide............... 2

2. Branches, leaves, pedicel, and calyx glabrous; leaves generally 4-6 times longer than wide; flowers actinomorphic, shaped like a five-pointed star; corolla lobes elliptic; stamens 5, isomerous; stigma ellipsoid, almost three times longer than wide........................Capraria mexicana 2. Branches, leaves, pedicels, and calyx variously hirsute, rarely glabrous; leaves (2-)3-4(-6) times longer than wide; flowers slightly zygomorphic but never bilabiate, with two upper petals closer together than any of the other three are to each other; corolla lobes oblong elliptic, stamens 4 or 5: when 4 , isomerous, didynamous or one longer than the other three, when 5 , then either isomerous, or two longer than the other three, to sometimes only one longer than the rest; stigma ovoid, almost 1.3 times longer than wide.

..Capraria biflora

Capraria biflora L., Sp.Pl. 2:628. 1753. Figure 1a, b, c, d; figure 4.

REPRESENTATIVE MATERIAL EXAMINED: MEXICO: Campeche: Pustunich, 10-08-1983, E. Góngora 1002
(CICY). Quintana Roo: Cobá village, 21-03-1994, R.R. Sears et al. 36 (CICY). Yucatán: Sierra Papacal, $6.3 \mathrm{~km}$ al NO hacia Chuburná Puerto, 11-09-1995, J.C. Trejo et al. 412 (CICY). Other 150 specimens examined from Mexico and the Yucatan Peninsula.

DISTRIBUTION: Mexico (Campeche, Chiapas, Guerrero, México, Nayarit, Oaxaca, Puebla, Quintana Roo, Sinaloa, Sonora, Tabasco, Veracruz, and Yucatán). Also United States of America (Florida), Central and South America (Williams, 2004).

DISCUSSION: Capraria biflora is the most widespread species of the genus in the New World and also in the Yucatan Peninsula area. The plant is readily distinguished by its branched stems, indument with eglandular hairs along branches, leaves, petioles, and calyx, more rarely glabrous. The petals are white or cream-white, the corolla slightly zygomorphic with 4 or 5 stamens and the stigma ovoid. Williams (2004) described C. biflora as having flowers zygomorphic to slightly regular, corolla white, bilabiate, tubular-funnelform, stamens 4 or 5 , didynamous, the longer pair exserted and the stigma ellipsoid. Williams (2004) keys out the same species (p. 62, 66) as having "stigma linear", creating confusion about this feature. Fortunately, the SEM photograph depicting the stigma shape of C. biflora (p. 58, fig. a, same publication) clearly shows an ovoid stigma such as we have observed in our material. Regarding the symmetry of the corolla, it is slightly zygomorphic but never truly bilabiate.

On the other hand, the type and position of the stamens in Capraria biflora need further comment. Although Williams (2004) described the stamens as didynamous, we find they are variable in number and length even within the same specimen. In our limited survey (a few plants, mostly from the Yucatan Peninsula), individual specimens presented flowers featuring either four or five stamens. Flowers with tetramerous androecium feature isomerous or didynamous stamens, while there is the occasional flower displaying a stamen longer than the other three. Flowers with pentamerous androecium show isomerous stamens or two longer than the other three, or even a single stamen longer than the rest. Mature flowers of $C$. biflora show fully exerted stamens (figure 1a) while this feature is not evident in herbarium specimens (figure $1 \mathrm{~b}, \mathrm{c}$ and $\mathrm{d}$ ) and in young flowers.

Plants referable to Capraria biflora have been collected in flower and/or fruit all year round. It is locally known as claudiosa (Spanish), box, chokuilxim hembra, and chokuilxim macho (Mayan). It has been locally reported as medicinal in the treatment of matrix bleeding, white refluxes, and pimps or acne.

Capraria frutescens (Mill.) Britton, J.Bot. 45:315. 1907. Figure $2 \mathrm{a}$ and $\mathrm{b}$; figure 5 . 

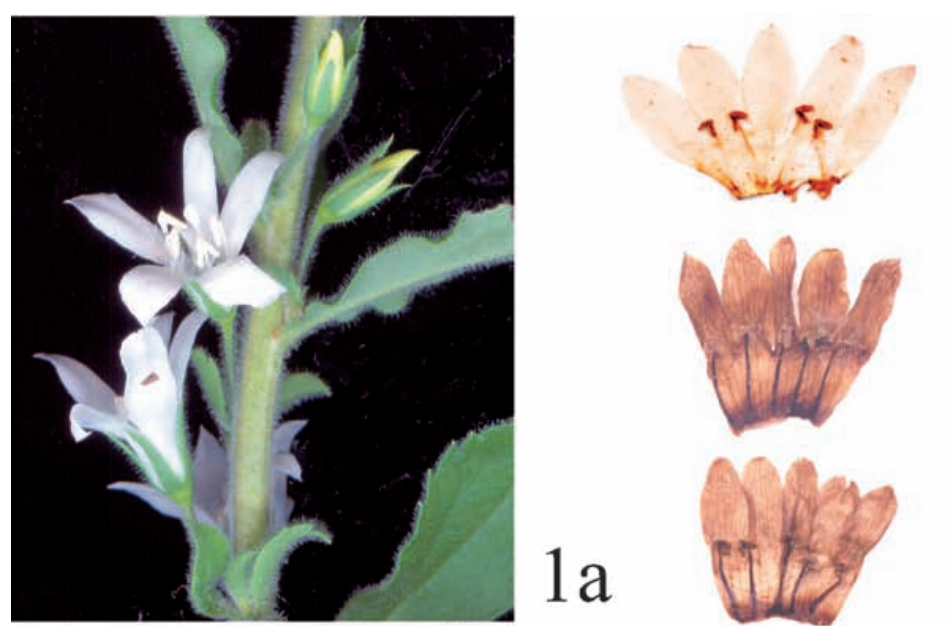

$1 \mathrm{~b}$

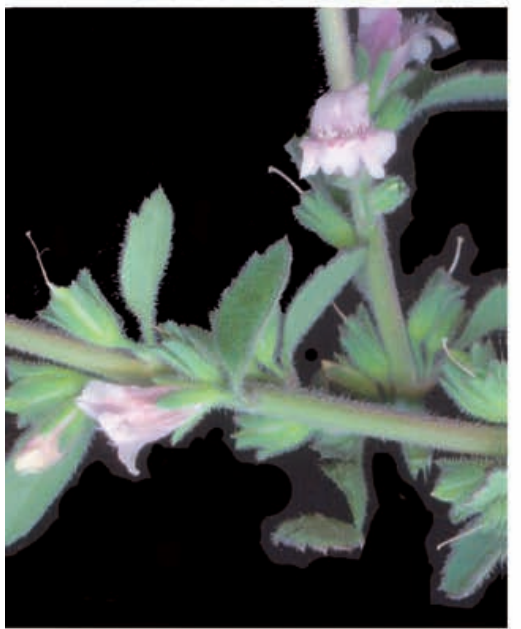

la

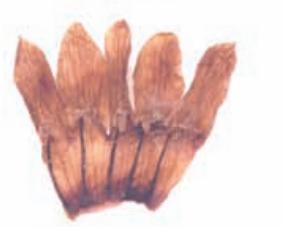

$1 \mathrm{c}$
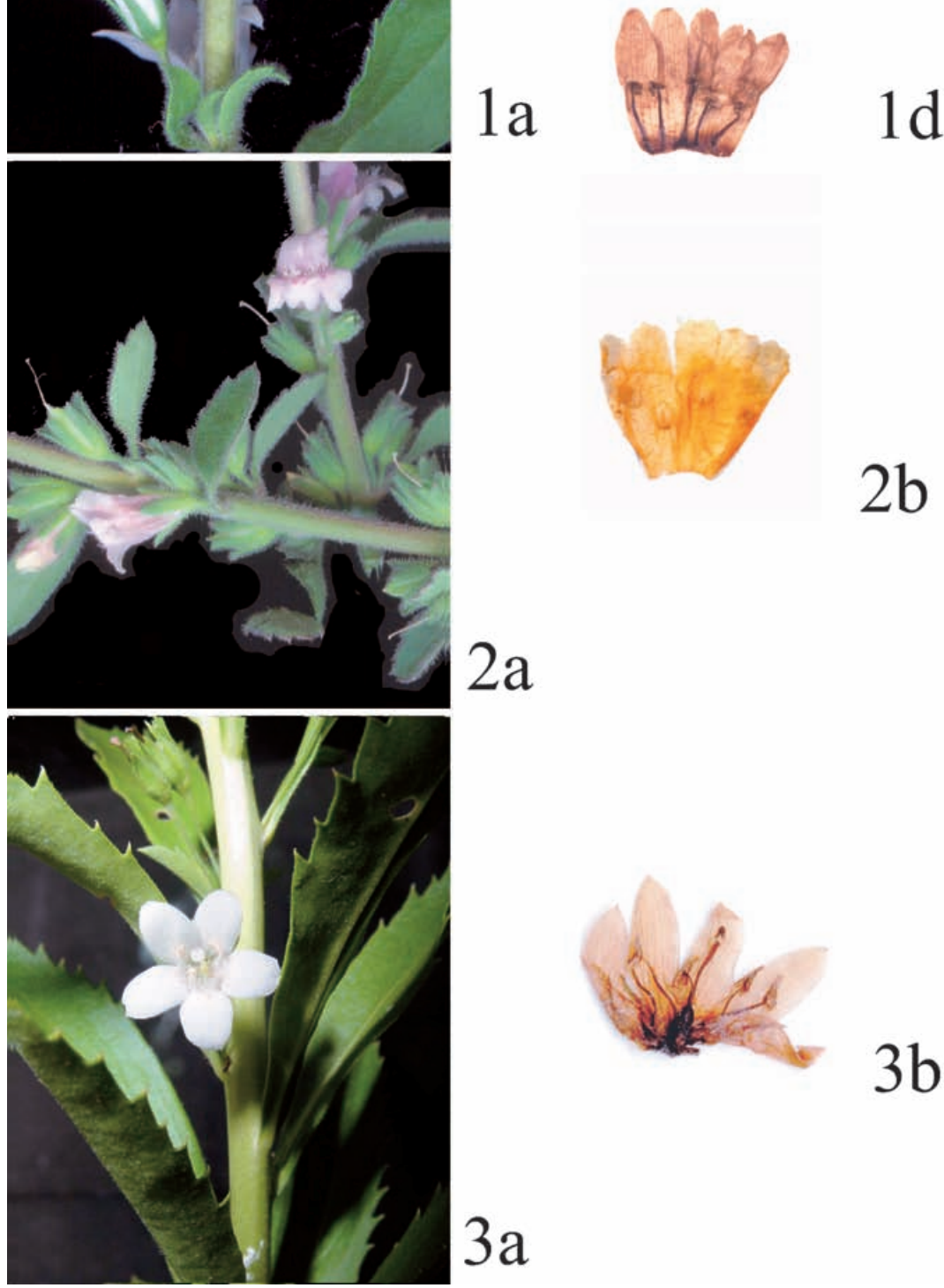

$2 \mathrm{a}$

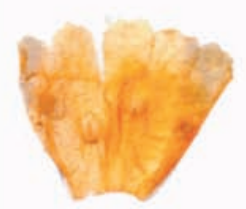

$2 b$

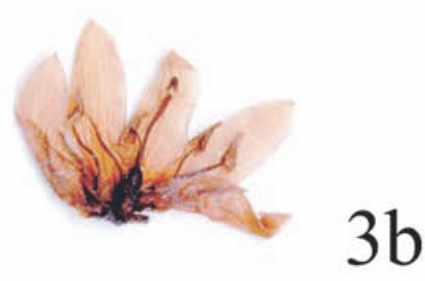

Figures 1-3. 1a-d: Capraria biflora L., a and b based on R. Duno de Stefano 2045, CICY, and $\mathbf{c}$ and d based on J.I. Calzada et al. 6768, CICY. a. View of the plant with flowers with four isomerous exserted stamens. b. Open corolla showing four isomerous stamens. c. Open corolla showing five isomerous stamens. d. Open corolla showing five stamens, two shorter. 2a-b: Capraria frutescens (Mill.) Britton, based on R. Duno de Stefano 2042, CICY. a. View of the plant with flowers. b. Flower showing four didynamous stamens. 3a-b: Capraria mexicana Moric. ex Benth., a based on R. Duno de Stefano 2088. CICY, and b on E Góngora 263, CICY. a. View of the plant with flowers with five isomerous and exserted stamens. b. open flower showing five isomerous stamens and an ellipsoid stigma. 


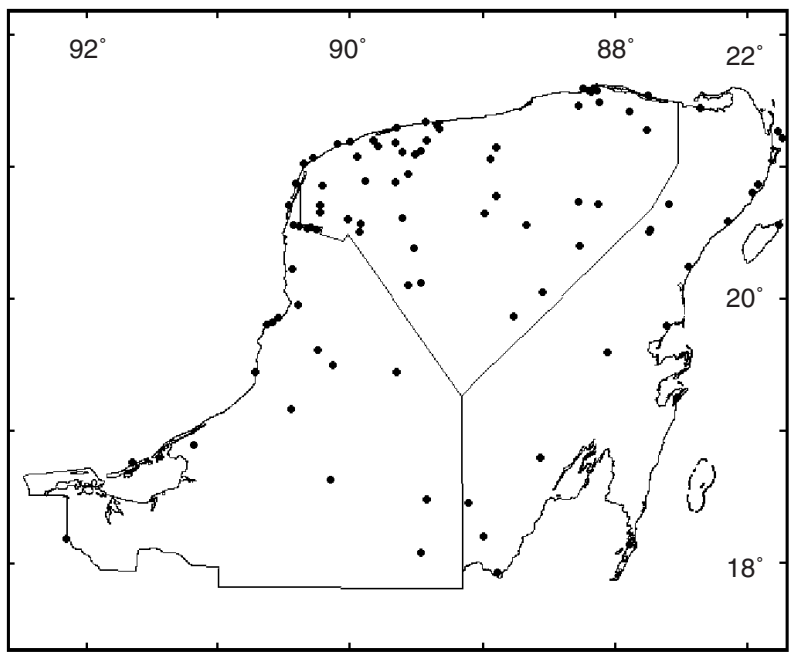

Figure 4. Distribution of Capraria biflora L. in the Mexican portion of the Yucatan Peninsula.

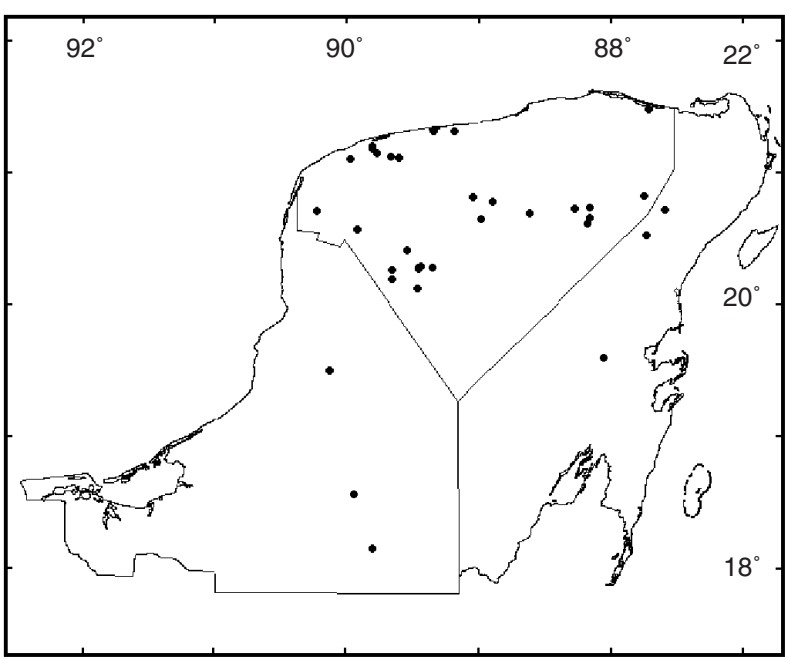

Figure 5. Distribution of Capraria frutescens (Mill.) Britton in the Mexican portion of the Yucatan Peninsula.

Erinus frutescens Mill., Gard.Dict. (ed. 8) Erinus no. 4. 1768. "Frutescens".

Capraria saxifragifolia Schltdl. et Cham., Linnaea 5:105. 1830. "saxifragaefalia".

REPRESENTATIVE MATERIAL EXAMINED: MEXICO: Campeche: Municipio Campeche, Pich, 29-08-1995, B. Faust y P. Ucán 486 (CICY). Quintana Roo: Tres Reyes,

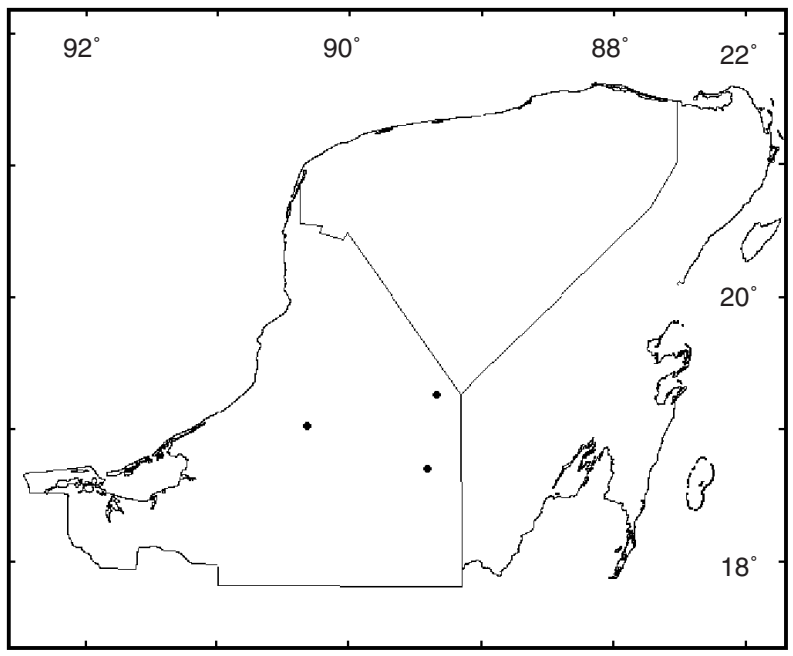

Figure 6. Distribution of Capraria mexicana Moric. ex Benth. in the Mexican portion of the Yucatan Peninsula.

23-09-1998, O. Stauning 190 (CICY). Yucatán: Municipio Kantunil, $15.5 \mathrm{~km}$ al E de Kantunil, luego del inicio de la autopista Mérida-Valladolid, 25-03-1999, G. Carnevali et al. 5362 (CICY). Other 50 specimens examined from Mexico and the PBPY.

DISTRIBUTION: Mexico (Campeche, Chiapas, Colima, Guerrero, Jalisco, México, Michoacán, Oaxaca, Querétaro, Quintana Roo, San Luis Potosí, Sinaloa, Tamaulipas, Veracruz, and Yucatán). Also Honduras (Williams, 2004). DISCUSSION: In the Yucatan Peninsula, the species is found mainly along the driest northern part, although a few scattered collections exist from more humid sections of the Peninsula. Capraria frutescens is easily distinguished by its monopodial stems with eglandular hairs along the stem and leaves, and glandular hairs in pedicels and calyx. The petals are white with purple spots or totally purple, the corolla is strongly zygomorphic (bilabiate), with four included, didynamous stamens, featuring a hemi-spheroid with the base concave (reniform in outline) stigma. The morphology as well as chromosome numbers (reported by Williams as $2 n=60$ ) suggest that the other three species of Capraria are more closely related among them than they are to this one.

In the Yucatan Peninsula, Capraria biflora and $C$. frutescens are often found growing sympatrically. However, no evidence of hybridization or introgression has been found. These two species have substantial differences in the morphology of the flowers; shape and color of the corolla and stamens (see figures 1 and 3). These differences suggest a divergent set of pollinators. Capraria frutescens has been collected in flower and/or fruit all year round. 
As other members of the genus, Capraria frutescens is locally known as claudiosa (Spanish), sek aax, and box (Mayan). It is reported as medicinal for coughs and sore wounds.

Capraria mexicana Moric. ex Benth. in DC., Prodr. 10:429. 1846. Figure $3 a$ and b; figure 6.

MATERIAL EXAMINED: MEXICO: Campeche: Municipio Carmen, $1 \mathrm{~km}$ al $\mathrm{O}$ de Centenario, sobre la carretera Escárcega-Chetumal, 27-03-1983, E. Cabrera y H. de Cabrera 15963 (MEXU); Municipio Calakmul, a 6.5 km al O de Flores Magón, 1848'56” N, 89¹3'43” O, 153 m s.n.m., 12-03-2002, J. Calónico Soto et al. 22673 (MEXU, UCAM); Yohaltún, selva alta, 9-04-1981, C. Chan y M. Burgos 332 (CICY); $10 \mathrm{~km}$ de Zoh-Laguna, camino para Xmaben, 07-04-1983, C. Chan 2065 (CICY); carretera Zotzil-Jaina, $20^{\circ} 12^{\prime}$ N, 90 $10^{\circ}$ ' O, 4 m s.n.m., en manglar, 14-03-1992, J.J. Ortíz 1913 (UADY); aserradero situado a la salida de Ucum, 07-04-1983, E. Góngora 263 (CICY); Yohaltún, selva mediana subcaducifolia, 30-051981, J.S. Flores y C. Chan 8707 (CICY). Quintana Roo: camino al Cenote Cocodrilo Dorado, cerca de la Unión y a 100 metros del Río Hondo, 1754'36” N, 8851'20” O, 12 m s.n.m., 27-03-2006, R. Duno de Stefano et al. 2054 (CICY); camino de Laguna Guerrero a Raudales, muy

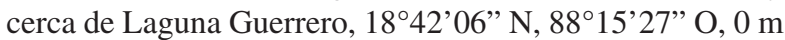
s.n.m., 28-03-2006, R. Duno de Stefano et al. 2073 (CICY); municipio Othón P. Blanco, Tres Garantías, desviación de la carretera Chetumal- Escárcega, $18^{\circ} 08^{\prime} 00^{\prime \prime} \mathrm{N}, 8^{\circ} 01^{\prime} 00^{\prime}$ " O, 0 m s.n.m., 01-08-2006, R. Duno de Stefano et al. 2088 (CICY). Additional material examined: Chiapas: Municipio de Tapachula, Puerto Madero, 26-03-1985, E. Ventura y E. López 1434 (CICY). Oaxaca: low-lying hill near Pacific Ocean, 2 kilometers east of Salina Cruz, 2506-1958, R.M. King 153 (MEXU). Tabasco: Ejido Corregidor Ortíz del Mezalapa, 30 m s.n.m., 22-04-1982, R. Escolástico 69 (MEXU).

DISTRIBUTION: Mexico (Campeche, Chiapas, Guanajuato, Jalisco, Oaxaca, Querétaro, Quintana Roo, San Luis Potosí, Tabasco, Tamaulipas, and Veracruz). Also United States of America (Texas), and Belize (Corozal and Stann Creek) (Williams, 2004).

DISCUSSION: Capraria mexicana represents a new record for the Mexican portion of the Yucatan Peninsula Biotic Province. It has been collected in the states of Campeche and Quintana Roo. We also include collections from Chiapas, Oaxaca and Tabasco, since we are not aware or any previous published records from any of these states. The species has not been cited in any of the floristic or monographic works relevant to these areas (Breedlove, 1986; Williams, 2004; Pérez et al., 2005). Capraria mexicana resembles a glabrous-leaved variant of $C$. biflora. However, a close examination of the flowers readily shows differences between these two closely related species, among them the ovoidal stigma in C. biflora (ellipsoid in $C$. mexicana), and the strikingly actinomorphic flower of $C$. mexicana. Furthermore, $C$. mexicana occurs in more humid areas.

According to Williams (2004), Capraria mexicana is very similar to the South American C. peruviana Benth., but distinguished by its longer styles and whitish corollas (greenish in C. peruviana).

Williams (2004) indicated that the species flowers from November through April and fruits from February through August. The specimens from our region have been collected in flower and fruits from March to May. It is possible that this species flowers and fruits year round. Capraria mexicana is locally known as chichibe (Mayan), and claudiosa (Spanish).

\section{Acknowledgments}

We are indebted to the curators of UADY and UCAM for specimen loans. We would like to thank Dr. Celene M. Espadas for her collaboration in assembling the distributional maps. The visit to MEXU carried out during this research was funded by the project "Flora Ilustrada de la Península de Yucatan" and by CICY (Centro de Investigación Científica de Yucatan, A.C.). Socorro González, an anonymous reviewer, and the editor of the journal greatly improved the manuscript with their suggestions.

\section{Literature cited}

Arellano-Rodríguez J.A., Flores-Guido J.S., Tun-Garrido J. and Cruz-Bojórquez M.M. 2003. Nomenclatura, Forma de Vida, Uso, Manejo y Distribución de las Especies Vegetales de la Península de Yucatán. Etnoflora Yucatanense, Fascículo 20. Universidad Autónoma de Yucatán, Mérida.

Balick M.J., Nee M.H. and Atha D.E. 2000. Checklist of the vascular plants of Belize. Memories of the New York Botanical Garden 85:1-246.

Barrera A. 1962. La Península de Yucatán como Provincia Biótica. Revista de la Sociedad Mexicana Historia Natural 23: 71-105.

Breedlove D.E. 1986. Listados Florísticos de México IV. Flora de Chiapas. Instituto de Biología, Universidad Nacional Autónoma de México, México, D.F.

Durán R., Campos G., Trejo J.C., Simá P., May-Pat F. y Juan-Qui M. 2000. Listado Florístico de la Península de Yucatán. Centro de Investigación Científica de Yucatán, A.C., Mérida.

Gutiérrez-Báez C. 2000. Listado Florístico Actualizado del Estado de Campeche, México. Universidad Autónoma de Campeche, Campeche.

Méndez-Larios I. y Villaseñor-Ríos J.L. 2001. La familia Scrophulariaceae en México: diversidad y distribución. Boletín de la Sociedad Botanica de México 69:101-121. 
Rodrigo DunO-De Stefano ET. AL.

Pérez L.A., Sousa-Sánchez M., Hanan A.M., Chiang F. y Tenorio P. 2005. Vegetación Terrestre. In: Bueno J., Álvarez F. y Santiago S. Eds. Biodiversidad del Estado de Tabasco, pp. 65110, Instituto de Biología, Universidad Nacional Autónoma de México y CONABIO, México, D.F.

Sosa V., Flores J.S., Rico-Gray V., Lira R. and Ortíz J.J. 1985. Lista Florística y Sinonimia Maya. Etnoflora Yucatanense,
Fascículo 1. Universidad Autónoma de Yucatán, Mérida. Tank D.C., Beardsley P.M., Kelchner S.A. and Olmstead R.G. 2006. Review of the systematics of Scrophulariaceae s.l. and their current disposition. Australian Systematic Botany 19:289-307.

Williams J.K. 2004. A revision of Capraria (Scrophulariaceae). Lundellia 7:53-78.

Received: October 18, 2005

Corrected version: October 9, 2006

Accepted: November 8, 2006 